\title{
Semiotic Analysis of Kerja Adat Erdemu Bayu in Karonese
}

DOI: https://doi.org/10.47175/rissj.v2i4.335

\section{| Dewi Juni Artha ${ }^{1}$ | Syakinah Sinulingga ${ }^{2}$ |}

Universitas Muhammadiyah Sumatera Utara, Indonesia

${ }^{1}$ dewijuniartha@umsu.ac.id ${ }^{2}$ syakinahsinulingga22@gmail.con

\begin{abstract}
This research deals with Semiotic Analysis of Kerja Adat Erdemu Bayu in Karonese. This research was aimed to find out the values and meanings contained in the Karo tribe's wedding ceremony so that people do not consider the ceremonial rituals as mere obligations and customs. This research used descriptive qualitative method. The data were taken from the video of the Karonese wedding ceremony on YouTube channel which uploaded on 07 May 2021 and also through interview from an elder who really understands the customs of the Karonese tribe, especially in wedding ceremonies. There were found 15 symbols, they are beka buluh (male's hood), uis jongkit dilaki (male's sarong), uis jujungjujungen (veil), uis ragi barat (sarong), amak tayangen (bed mat), kalang ulu (pillows), perembah (long chloth, baby carrier), beras meciho (pure rice), naruh manuk (egg), sumpit (basket rice), uis nipes (traditional cloth), lampu terlong (oil lamp /lamp), kudin (cooking pot), manuk asuhen (hen), perkakas dapur (kitchen utensils) each of which has an interpretation in the form of advice, prayers and wishes for the bride and groom in living their domestic life.

KEYWORDS

Semiotic; symbol, Karonese Wedding Ceremony
\end{abstract}

\section{INTRODUCTION}

Indonesia is a country that has various ethnic groups and cultures. According to the 2010 statistical census, there were 1,340 ethnic groups. Each tribe in Indonesia has different customs, this is due to the influence of geographic location, natural conditions and community conditions when the culture was created.

The Karonese is a tribe in North Sumatra. The Karonese is the tribe in North Sumatra which has separate languages, customs, clans, and ceremonies. The kinship system in the Karonese is regulated by the merga silima, rakut sitelu tutur siwaluh. The clans in the Karonese consist of five clans, namely Karo-Karo, Ginting, Tarigan, Sembiring and Perangin-angin and each clan has sub-clans (Sembiring, 2018). A person from the same clan is prohibited from marrying because he is like a sibling and is a part of Karonese tribal customs (Singarimbun, 1973). One of the characteristics of the Karonese is in traditional dress which is dominated by red and complemented by supporting golden jewelry ( Sitepu and Ardoni, 2019). The choice of red color certainly has an implied meaning in it, a meaning based on the beliefs or ideology of the Karonese itself.

Furthermore, there is very little insight and knowledge of culture. This happens because of the lack of awareness of young people to learn about the culture that exists in their tribe which makes their knowledge limited. Likewise with the Karonese youth ethnic who have begun to forget things related to the Karonese culture because it has been contaminated with external cultures such as western culture so that if this happens then the Karonese culture that has been formed by their ancestors will be lost and replaced with other cultures that are no longer reflects the local values of the Karonese. 
As has been passed before, to maintain the preservation of Karonese culture, it is necessary to introduce and understand the traditional and cultural traditions of the Karonese to the young generation through signs on objects that contain values and meanings. Culture and symbols are related to one another. Every culture has patterns and these patterns are implied by meanings that contain historical values, patterns, in the form of symbols by semiotic learning. According to Sebeok (2001), a sign is any physical form that has been imagined or produced externally (through some physical media) to reflect entities, eyes, feelings, or other referential domains. Signs serve a number of roles in human life. They enable people to identify trends in things; they serve as predictive guides or plans for actions; they serve as exemplars of specific types of phenomenon; and the list goes on.

Semiotics is the science that studies the signs contained in an object in order to get a complete understanding. Linton, (1945) states that a culture is the configuration of learned behavior and the outcomes of behavior, the components of which are shared and transmitted by members of specific society.

In general, traditional ceremonies are all forms of activities carried out by the community on a regular basis with an implementation process that is in accordance with the beliefs of the local community. Koentjaraningrat, (1992) claimed that all forms of events attended by the community that can bring about awakening within them are known as traditional ceremonies.

In Karonese culture, ceremonies are part of customs that must be carried out, the ceremony has a special ritual in which it is carried out based on the type of ceremony being held. Some of the ceremonies that are often carried out by the

Karonese are Mbaba Anak Kulau, Erbahan Gelar, Ergunting, Death Ceremony Cawir Metua and Kerja Adat Erdemu Bayu (Wedding Party). From the several ceremonies, one of the things that must be carried out by each Karonese is the Kerja Adat Erdemu Bayu , which is a marriage ceremony between a man and a woman so as to form a happy family bond between the two.

There are various kinds of processes or stages in the implementation of the Karonese wedding ceremony, such as; Nungkuni, Mbaba belo selambar, Nganting manuk, Kerja adat, Mukul, Ngulihi tudung, and Ertaktak. In Kerja adat, there are several rituals that must be followed by the bride and groom in interpreting the wedding ceremony, and these rituals contain symbols that have important meanings. However, often both the Karonese and non-Karonese tribe still does not know the meaning of the symbols contained in this tradition. They only know that Kerja Adat Erdemu Bayu wedding ceremony as one of the Karonese tribal ceremonies that have been obtained from generation to generation from their previous ancestors without knowing the true meaning and even some people have started to shift this ceremony into a ceremony that is packaged in a more modern element by leaving the original elements of the culture, itself.

This research focuses on semiotics in a Karonese wedding ceremony using Charles Peirce's theory of semiotics which includes objects, signs, and interpretations. This study was limited to the meanings and symbols in Pengendesen Luah that was giving of gifts to the bride and groom contained in the Karonese wedding ceremony.

\section{LITERATURE REVIEW}

\section{Semiotics}

Semiotics comes from the Greek word semeion, which means sign. In terms of terminology, semiotics can be defined as the study of a wide range of objects, events of all 
cultures as signs (Sobur, 2001). According to Zoest (in Piliang, 1999: 12) semiotics is the science of signs, which functions to produce meaning. Sign is something that for someone is something else, can be observed so that the sign is not only limited to an object, as well as the presence or absence of events, structures, habits, which are found in something.

Semiotics is generally divided into 3 branches, such as semantics, syntax, and pragmatics, all of which are connected to one another.

a. Semantics: the study of the relationship between signs and the significance of the meaning.

b. Syntax: the study of meanings individually or in combination with descriptive analysis.

c. Pragmatics: study of the use of concrete signs such as effects and impacts that occur between signs and users in the event.

\section{Charles Sanders Peirce's Theory of Semiotics}

According to Charles Sander Peirce's Semiotic Theory, semiotics is based on logic, because logic studies how people reason, while reasoning according to Peirce is done through signs. According to Peirce, these signs allow us to think, relate to other people and give meaning to what the universe represents.

In this case, humans have a variety of signs in various aspects of their life. Where the linguistic sign is one of the most important. In this semiotic theory the function and use of a sign is the center of attention. Signs as a means of communication are very important in various conditions and can be used in various aspects of communication.

\section{Peirce Classification of Signs}

Peirce wanted his semiotic theory to become a general reference for the study of signs. Therefore, he needs a more in-depth study on this matter. Especially regarding how broad the scope of this theory is. for that he divided them into several classifications.

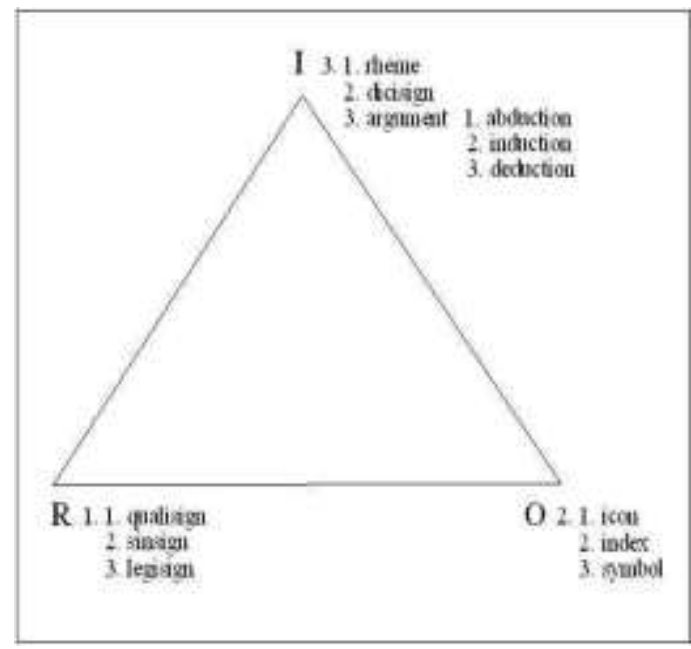

Diagram 1. Pierce's semiotic model

\section{Culture}

The word culture itself comes from the Sanskrit language, which is budhayah, which is the plural form of buddhi with the meaning of mind or reason. Whereas in English culture is known as the word culture which comes from Latin, namely colore, which means processing or working. 
The term culture itself is also used in Indonesian with the upturned word "budaya". Culture is associated with a part of human mind and reason.

Culture is a pattern or way of life that continues to develop by a group of people and is passed on to the next generation. According to M. Selamet Riyadi, culture is a form of love from our ancestors that is passed on to all their descendants. Bronislaw Malinowski said that four main elements of culture include:

a. A system of social norms that allows cooperation between members of the community to adapt to the natural surroundings

b. Economic organization

c. Tools, and institutions or officers for education (the family is the main educational institution)

d. Power organization (politics)

Koentjaraningrat, divides the form of culture into four parts, such as:

1. Cultural Values

This term, refers to the mention of cultural elements which are the center of all other elements. Cultural values are ideas that have been studied by residents from an early age, so they are difficult to change. This idea is what then results in various objects created by humans based on their values, thoughts and behavior.

2. Cultural Systems

In this form, culture is abstract so that it can only be known and understood. Culture in this form is also patterned and based on certain systems.

3. Social System

Social systems are patterns of human behavior that describe the form of human behavior that is carried out based on the system. Culture in this form is concrete so that it can be perpetuated.

4. Physical Culture

This physical culture is the greatest form and is also concrete. For example, magnificent buildings such as the Borobudur temple, moving objects such as tankers, computers, plates, glasses, buttons for clothes, and others.

Culture has various characteristics, according to each ethnic group which influences the creation of different languages, social life, norms, religions and values. It is a legacy from our ancestors that must be preserved so that it remains sustainable and exists until our children and grandchildren later.

\section{Karo Tribe Wedding Ceremony}

Marriage is an event that is very important for the Karo tribe because it is a part of the life of the Karo people. Through a marriage there will be an inner relationship between a man and a woman who will become a new family so that the bride and groom can get to know the extended family of both parties. The Karo community, recognizes marriage as a bond between a man and a woman which is regulated by religion, as well as customs and is based on the rules of culture in force in the Karo tribe, so that marriage can be approved and accepted by the Karo family and community. The implementation of these customs aims to ensure that when they become husband and wife, there is no same clan marriage, or marriage that violates the rules of the kinship system. But marriages that are allowed are such as marriage with different clans or are referred to as "Erimpal".

Furthermore, in carrying out a wedding tradition there are things that must be prepared to create a well-executed wedding ceremony. Before carrying out the core activities in the 
form of "Kerja Adat" of the Karo tribe wedding ceremony, there are several steps that must first be carried out so that the wedding tradition is carried out perfectly, namely

1. Nungkun Kata / Sitandan: This is the initial stage which is usually referred to as an introduction. Get acquainted with each of the family parties of the bride and groom who will later get married.

2. Mbaba Belo Selambar: This is the next stage, after Nungkun kata stage. This stage is also called the application stage.

3. Nganting manuk : At this stage, both the groom and the bride discuss the certainty that has been determined in the previous stage, the time for the implementation of nganting manuk is usually before a traditional party is held, and is generally held on the evening before the $\mathrm{D}$ day of the traditional party.

4. Kerja Adat : Is the core activity of a series of processes in the Karo tribe wedding ceremony. This activity is carried out in accordance with the predetermined time. Party The traditional wedding party or so-called Kerja Adat Erdemu Bayu Customary which is held for one day, which takes place in the bride's village

5. Mukul: After a full day of traditional party, then in the evening, a mukul event which is often called persadan tendi is held, to confirm the marriage that has been carried out. Mukul is attended by the closest relatives of the bride and groom respectively.

6. Ngulihi tudung / ngulihi bulang: The ngulihi tudung ceremony is held after four days of the mukul event.

7. Ertaktak: The meeting held at the Kalimbubu house aims to discuss related expenses.

\section{RESEARCH METHODS}

This research was used descriptive qualitative research. Qualitative descriptive method was used to analyze the semiotics of the Karo traditional wedding on the YouTube channel. Analysis of the video documentation was carried out to find the signs contained in the Karo traditional wedding party on YouTube. In addition to analysis, the interview was also conducted to prove the validity of the data.

This research did not make direct observations, due to the Covid-19 pandemic so the village head did not allow actions that caused crowds such as holding a wedding party following the rules from the central government. Therefore, the research data was obtained from wedding events on YouTube. https://youtu.be/CGgOryfWe2c accesed on August, 2021. In addition, researcher also got the data through interview from an elder who really understands the customs of the Karonese tribe, especially in wedding ceremonies. The informant is Mrs. Bena Malem Br Karo (80 years old).

RESULTS AND DISCUSSION

Beka Buluh (Male's Hood)

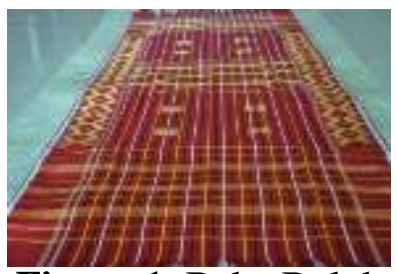

Figure 1. Beka Buluh 


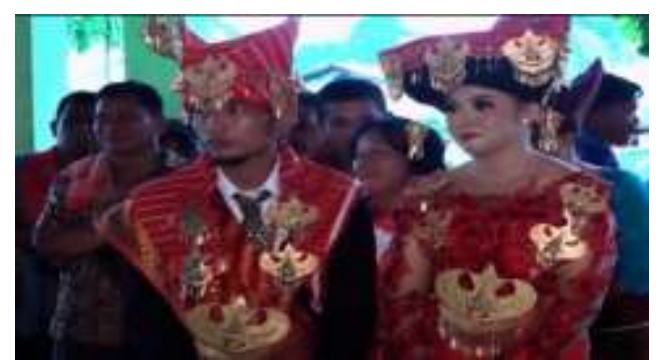

Figure 2. The groom used beka buluh

Beka Buluh was a red cloth that comes from the Karo Tribe. The use of the Beka Buluh in Karonese activities was usually at traditional events. Generally, Beka Buluh was used by men, as a head covering during traditional events, the Karo people call it Bulang. Beka buluh also used on the shoulders of men when a traditional event held.

The beka buluh, which was placed on the head as a hood symbolizes the crown of men, which was interpreted that men as leaders in the household and as heirs of descendants / clans in the family have great responsibilities and roles in the family and social environment.

\section{Uis Jongkit Dilaki (Male's Sarong)}

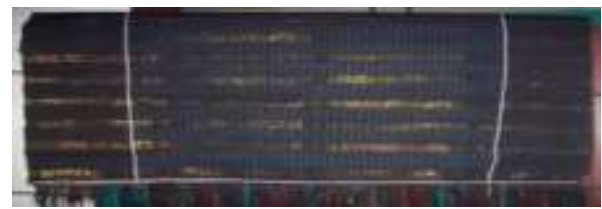

Figure 3. Uis jongkit dilaki

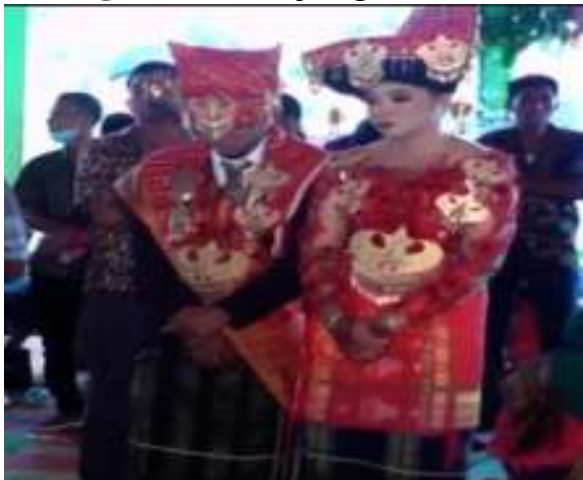

Figure 4. The groom used uis jongkit dilaki

Uis jongkit dilaki was a cloth used as the lower outer garment for men. The use of this cloth is the same as the use of a sarong in general. This cloth was used by the sons of Karo for all traditional ceremonies that require full traditional dress. The interpretation of wearing Uis Jongkit for men was to show a strong, and mighty character.

\section{Uis Jujung-Jujungen (veil)}

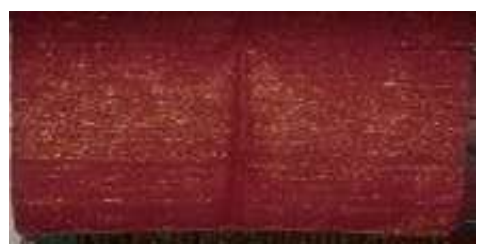

Figure 5. Uis jujung-jujungen 


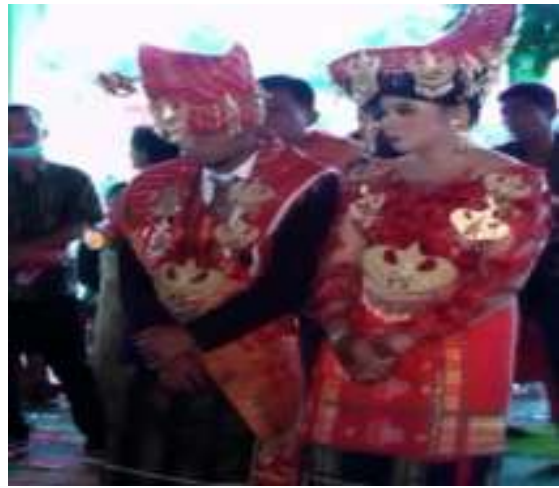

Figure 6. The bride used uis jujung-jujungen

Uis Jujung-jujungen was a cloth used for the outer layer of Karo women's head coverings during traditional parties combined with gold tassels on the front. Uis Jujungen was part of the Tudung teger limpek (the veil worn by the bride), interpreted as a form of a woman who was beautiful and has good character, who was expected to be able to help her husband in the future.

\section{Uis Ragi Barat (sarong)}

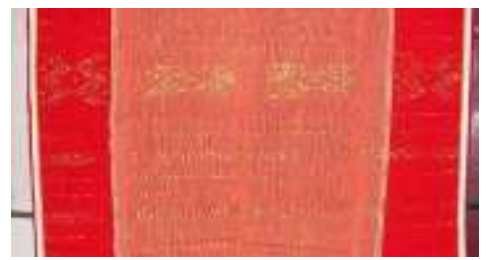

Figure 7. Uis ragi barat



Figure 8. The bride used uis ragi barat

Uis ragi barat was a red cloth and has a motif of gold threads. The bright red color contained in this cloth was interpreted as a bright heart and enthusiasm when attending an invitation or an event, was supported by the fact that Karo women only wear this during joyful events such as weddings by being used as a scarf. In addition, the cloth also used as the outer layer of the lower women's clothing, namely as a sarong in traditional ceremonies that are joyful when required to wear full traditional clothes. 


\section{Amak Tayangen (Bed mat)}

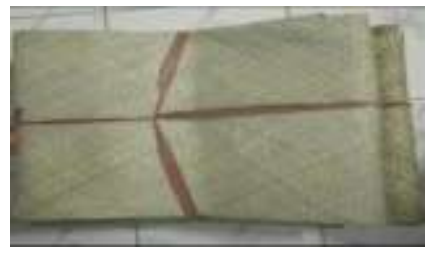

Figure 9. Amak tayangen

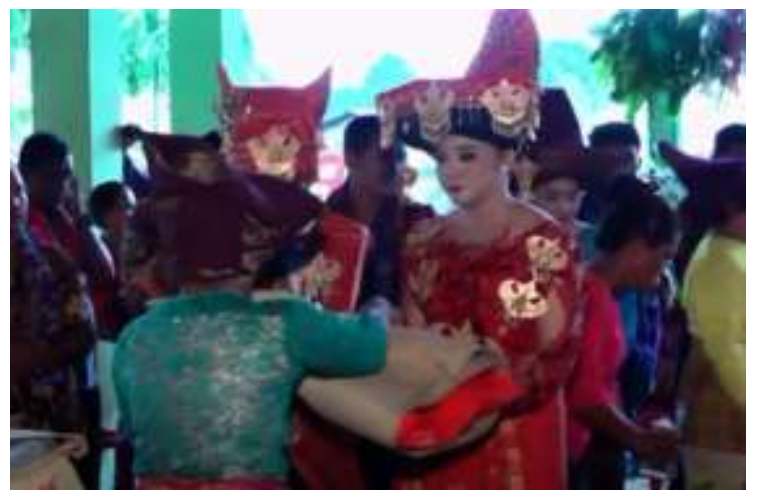

Figure 10. Amak tayangen given to the bride and groom

Amak Tayangen was a large and wide white mat made of woven pandanus leaves. At the moment of giving amak tayangen will gave included with a pillow. This mat became a symbol of the bridal bed. The interpretation of giving this mat was that the mat was a place to rest when the body and mind are tired. In addition, when resting, husband and wife can exchange ideas about their hearts and problems with each other so that harmony can be realized. And after that they become excited again in working and living a married life.

\section{Kalang Ulu (Pillows)}

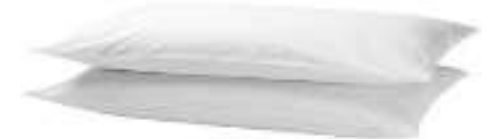

Figure 11. Kalang ulu

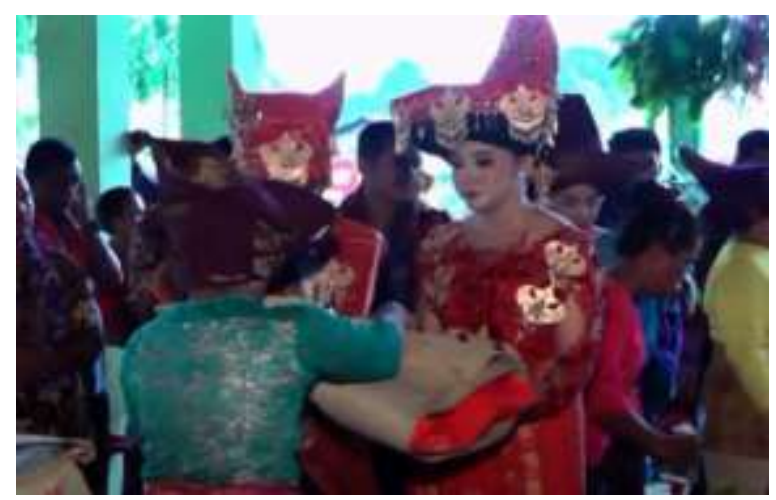

Figure 12. kalang ulu given to bride and groom

Kalang $u l u$ was a term for pillows. The Pillows were used to elevate the head position while sleeping. The Pillows were given as many as two pillows rolled together with the 
mat. The pillow used to be a head pillow, without a bolster pillow. The symbol of kalang $u l u$ has an interpretation of giving kalang ulu so that every activity that has carried out will be upstream, especially in work and income. Also, after taking a break, the mind becomes calm in dealing with problems in the household, so as to create harmony in the household.

\section{Perembah (Long chloth, baby carrier)}



Figure 13. Perembah

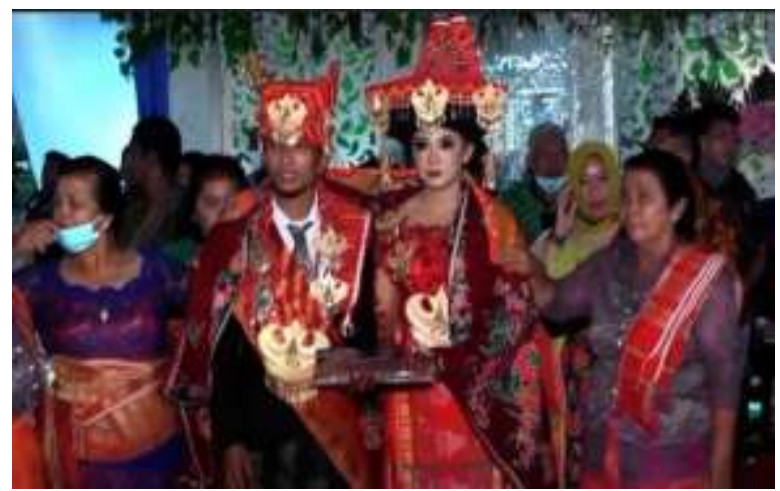

Figure 14. Perembah given to bride and groom

Perembah was a long cloth and the ends are not joined together. Perembah was very often used in Karo customs such as gifts given when they have children. Perembah means a sling, which was used by the Karo people to hold their babies. Perembah became the most widely handed out gifts, because almost all parties have a part to give this long cloth, from the kalimbubu to the anak beru. At the time of giving, this cloth will be stretched to the shoulders of the bride and groom and then tied.

The Perembah symbol was given during the Karo traditional wedding party as an interpretation of being blessed by all parties such as kalimbubu, anak beru and others as well as hopes and prayers for having children as soon as possible so that later they can use the perembah given to carry their child. In addition, the perembah, which was a long cloth, is likened to the hope that the fostered household will live long enough to have children and grandchildren.

\section{Beras Meciho (Pure Rice)}



Figure 15. Beras meciho 


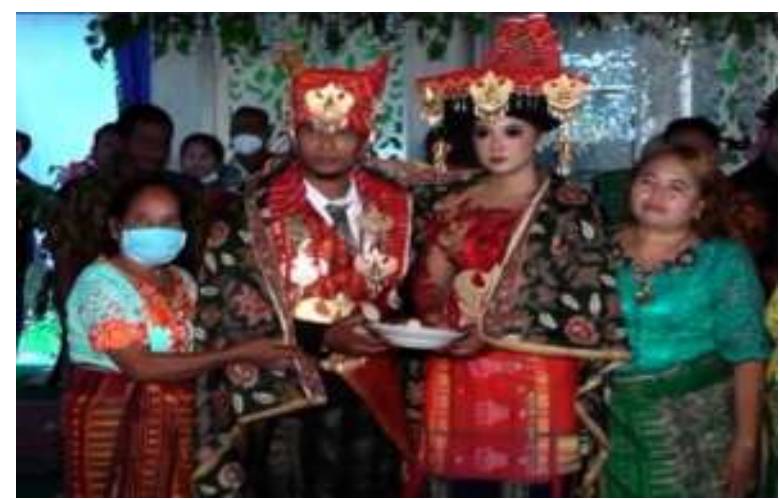

Figure 16. Beras meciho given to bride and groom

Beras meciho were white rice. It was said to be meciho which means clean or white in Karo. The symbol of rice, which was a basic need which is the main source of food was given at Karo traditional weddings so that later it can be cooked and eaten by the bride and groom after forming a family. Beras meciho were served along with chicken egg which are placed in the middle of the rice on a ceramic plate or white ceramic bowl. The choice of white color means pure and sincere. Rice was produced by the Karo people, most of whom are farmers, so rice is very meaningful because it was also a source of livelihood. The meaning in handing over beras meciho were so that in marriage they always put forward a clear mind when facing problems, and have a sincere and a clean soul like rice so that later their family will become a good family.

\section{Naruh Manuk (Egg)}

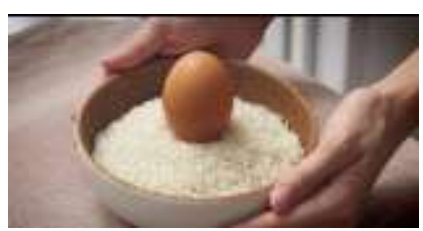

Figure 17. Naruh manuk

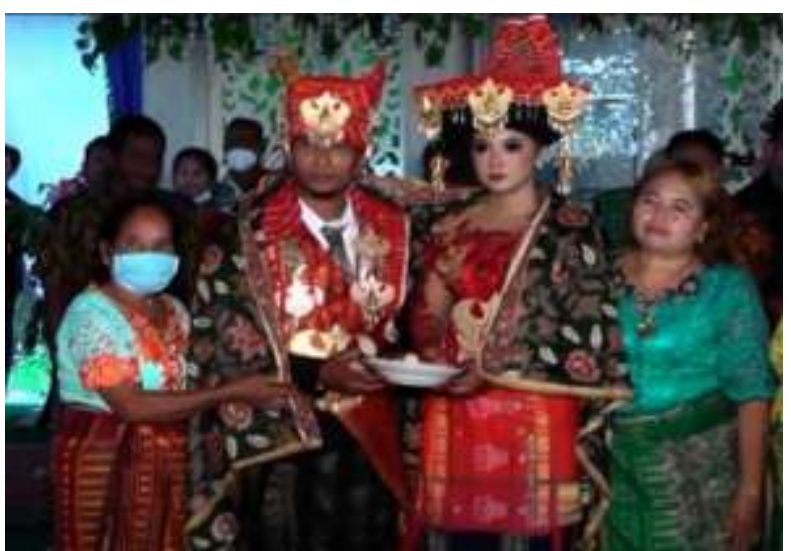

Figure 18. Naruh manuk given to bride and groom

Naruh manuk is a term for chicken eggs. The egg was given to the bride and groom along with beras meciho. The egg was placed in the middle of the rice so that it can stand upright. The egg was symbolized as the meaning of life, because inside the egg will later become a chicken. The egg used in the event was free- range chicken egg, because the Karo people in the past liked to raise native chickens, so the eggs were easy to get. 
However, along with the times, and the lack of land, some Karo people no longer keep native chickens so that the use of free-range eggs can be replaced with European chicken eggs which are easily obtained.

The interpretation of giving naruh manuk was so that the marriage was carried out into a precious marriage, the bride and groom can hold fast to the promises they have made, maintain household harmony, so that other people will see it as respectable family.

\section{Sumpit (Basket rice)}

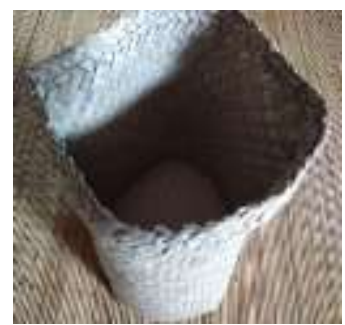

Figure 19. Sumpit

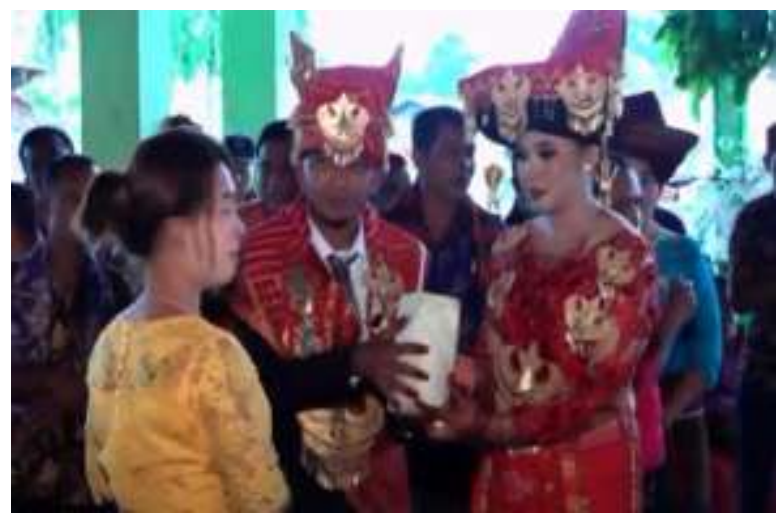

Figure 20. Sumpit given to bride and groom

Sumpit was a container for storing rice made of woven pandan leaves. Sumpit was often used by the Karo people in traditional ceremonies, sumpit filled with rice was interpreted as a sense of joy at the invitation of an event which has the meaning of giving a blessing to the host of events such as entering a new house, wedding ceremony.

\section{Uis Nipes (Traditional cloth)}



Figure 21. Uis nipes 


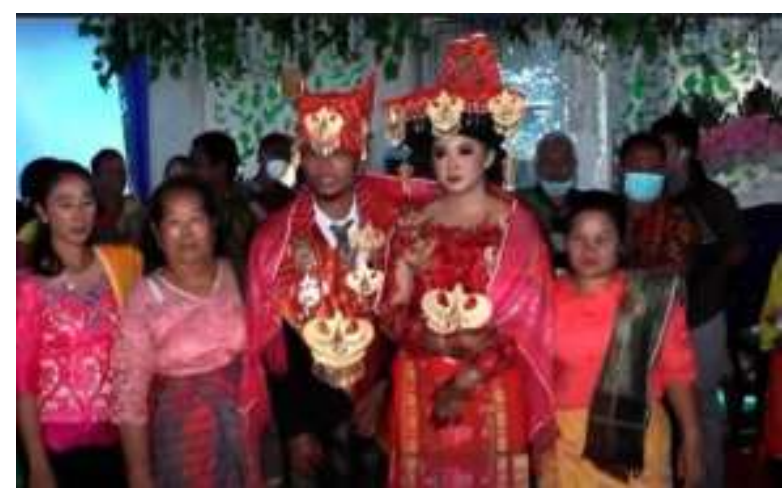

Figure 22. Uis nipes was given to bride and groom

Uis nipes was a cloth whose use is very often seen in almost all Karo traditional events. Uis nipes which was a typical Karo cloth has a function as a scarf used by Karo women when attending traditional parties. Uis nipes used by married women when attending traditional parties, it was interpreted that the woman already has responsibilities in all social aspects including the responsibility to attend, invitations to events related to customs and carry out tasks according to the roles given, especially in terms of family and customs.

\section{Lampu Terlong (oil lamp /lamp)}
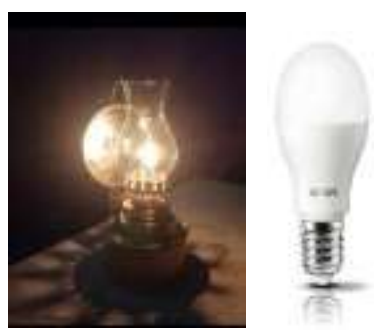

Figure 23. Lampu terlong

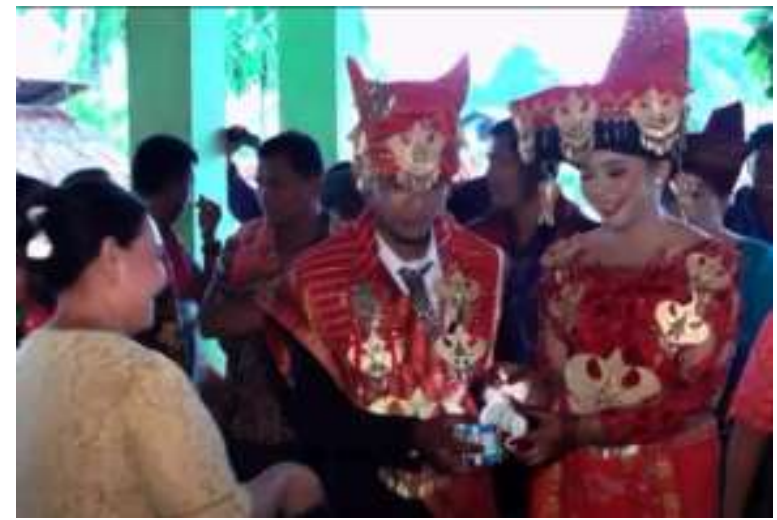

Figure 24. Lampu terlong given to bride and groom

Lampu terlong or kerosene lamp was an object that serves to illuminate. This lamp was a lighting device using kerosene which is absorbed by the wick so that it can produce light. This lamp was given at the time of pengendesen luah at a traditional wedding ceremony, but along with the times and technological advances, the Karo people had started to forget these ancient lamps, so their use was replaced by modern lamps such as Led lamps that use electricity.The interpretation of giving the lamp, so that the living lamp can illuminate the darkness, just like the bride and groom later, the living lamp can illuminate her dark house 
so that there was a bright relationship and in dealing with problems solved by brightening the heart and mind so that the family they care for will later become a harmonious family.

\section{Kudin (cooking pot)}

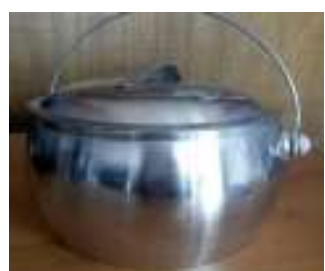

Figure 25. Kudin

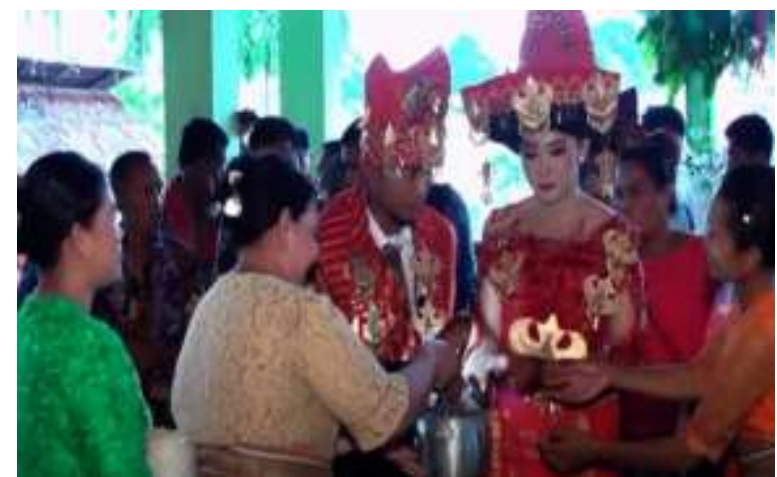

Figure 26. Kudin was given to bride and groom

Kudin or pot was a kitchen utensil used to cook rice. In the past, the Karo people did not know the electronic rice cooker or rice cooker, so they cooked rice using a pot. The Karo people believe that by cooking rice using kudin, the taste of the rice would tastier and fluffier. Kudin was handed over so that later the wife could cook rice for her husband. The interpretation of the kudin symbol according to the Karo tribe was as a living in the household, so that later the bride and groom having a family can find and fulfill their life needs independently and in their family life they will become persistent and responsible parents for their children later.

Manuk Asuhen (Hen)

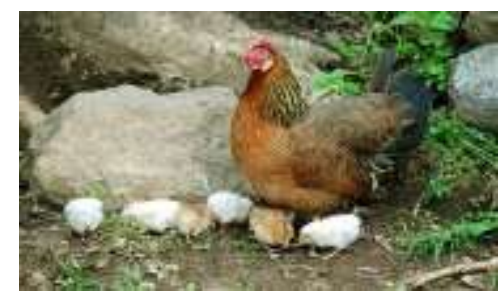

Figure 27. Manuk asuhen 


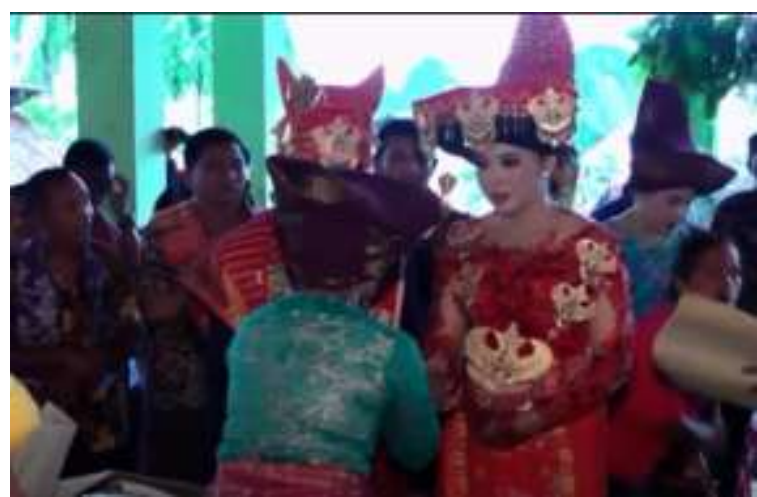

Figure 28. Manuk asuhen's substitute given to bride and groom

Manuk asuhen or chicken was luah/gifts in the form of chicken given to the bride and groom to be cared for. These chickens will later be reared until they are large, then produce chicks. The symbol of manuk asuhen was interpreted so that later in the family, it was like a hen who has children, protects her children, and loves her family. In this video, manuk asuhen was not given symbolically but money as a substitute for chickens because native chickens at the time of the event were difficult to find due to the bird flu outbreak.

For the people of Karonese, chicken was the interpretation of special food as a form of splendor or respect. Chicken was often consumed by the Karo people in certain events such as the mbesur-mbesuri event (7 months for pregnant women), mbereken nakan man orang tua (giving food for the parent). In addition, chicken was also consumed when welcoming guests at home, which means that the guest is highly respected and as a form of joy for the guest to come home. This is the reason for giving manuk asuhen so that later it can be useful for the bride and groom in their family.

\section{Perkakas Dapur (Kitchen Utensils)}



Figure 29. Perkakas dapur

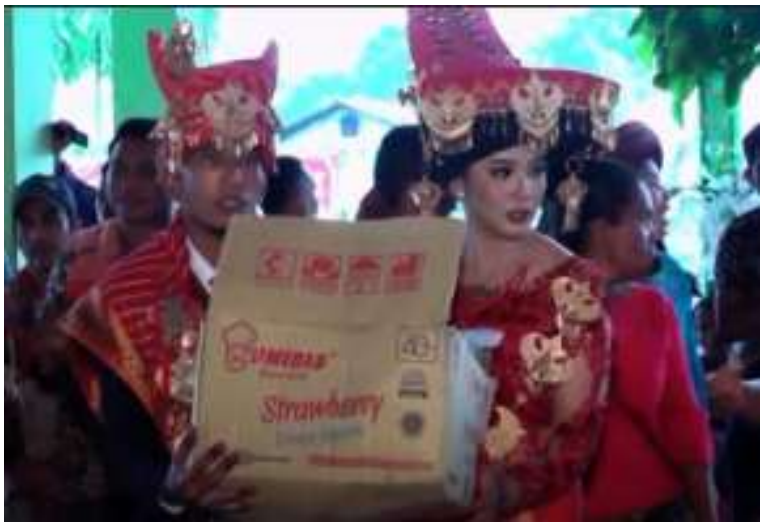

Figure 30. Perkakas dapur given to bride and groom 
Perkakas dapur are items for kitchen equipment. Kitchen utensils usually consist of plates, spoons, kettles, cauldrons and other kitchen utensils.

This kitchen utensil would give to the bride and groom arranged in one box. The interpretation of the symbol of kitchen utensils as a provision for the bride and groom to take on a new married life, as well as being an inspiration to live independently so that later they can buy and add their own household equipment without burdening household matters to parents from both parties.

\section{Finding}

Based on the analysis there were 15 materials obtained in Kerja Adat Erdemu Bayu in Karonese wedding ceremony, they are : beka buluh, uis jongkit dilaki (male), uis jujungjujungen, uis ragi barat, amak tayangen, kalang ulu, perembah, beras meciho, naruh manuk, sumpit, uis nipes, lampu terlong, kudin, manuk asuhen, kitchen utensils, each of which has its own meaning.

The groom's clothing such as beka buluh has the meaning of valor and might by the groom while uis jongkit is a symbol of the groom's ethics and manners in dressing. Bride's clothes such as uis jujungen, uis ragi barat, uis nipes have the meaning of being a beautiful karo woman, having good character and having responsibility in the family and social environment and always keep her honor.

Pengendesen luah such as amak tayangen, kalang ulu, perembah, beras meciho, naruh manuk, sumpit, lampu terlong, kudin, manuk asuhen, and kitchen utensils have meanings as a form of happiness for the bride's wedding so that gifts are given in the form of things that can later help the bride and groom in carrying out family life. As well as in giving the luah, there were an interpretation of the luah in the form of hopes and prayers of kindness for the bride and groom, namely being blessed with offspring, loving each other, solving all problems well, and being able to live independently in the family.

Through videos of Karonese wedding ceremony on YouTube, people, especially the young generation, are more interested in getting to know customs because they are accompanied by music and can be downloaded and accessed anywhere via cell phones, so the Karonese and non-Karonese as well as the young generation are familiar with and know the customs of Karonese weddings.

In addition, by looking at the process of Karonese traditional wedding, starting from the clothes, music, and the values and meanings contained in the custom, it is not impossible for people who are non-Karonese to be interested in getting married using a Karonese traditional wedding ceremony

\section{Discussion}

In this study, it was known that the implementation of the traditional wedding ceremony in the Karonese has signs in which there are values and meanings from the process of carrying out the event. Analysis of the signs can use the theory of Charles Sanders Pierce that is namely representation, interpretation and object.

Kerja Adat Erdemu Вауи is a marriage ritual of the Karo tribe, this wedding ceremony aims to hand over the bride to the groom by following a series of customary processes including paying a dowry to the woman (kalimbubu).

In the implementation of Kerja Adat Erdemu Bayu wedding ceremony, there are symbols that have the meaning of goodness which can be used as guidelines in living a family life. The symbols interpreted in this ritual has values that were in accordance with everyday life. Kerja Adat Erdemu Вауu wedding ceremony in Karonese is one of the 
traditional ceremonies of the Karo tribe that must be maintained in order to remain sustainable in the future. The younger generation, especially the Karo people, must learn to know and understand the values and meanings contained in traditional ceremonies, through this research, so this ritual can be carried out and can be witnessed by our children and grandchildren later.

\section{CONCLUSION}

Based on data analysis, the following conclusions could be drawn:

1. From the Kerja Adat Erdemu Вауи In Karonese video, there were 15 materials in which there were 15 symbols, namely beka buluh (Male's hood), uis jongkit dilaki (male's Sarong), uis jujung-jujungen (veil), uis ragi barat (sarong), amak tayangen (bed mat), kalang ulu (pillows), perembah (long chloth, baby carrier), beras meciho (pure Rice), naruh manuk (egg), sumpit (basket rice), uis nipes (traditional cloth), lampu terlong (oil lamp /lamp), kudin (cooking pot), manuk asuhen (hen), kitchen utensils (kitchen utensils), each of which has its own meaning.

2. The values and meanings contained in the signs found in the Kerja Adat Erdemu Вауи In Karonese were advised, prayers and hopes for the bride and groom in living their domestic life.

\section{Suggestion}

There are some suggestions as follows

1. For linguistic learner in conducting research, it is recommended to increase the knowledge of linguistic studies, especially in the field of semiotics so that they can increase their knowledge as well as a reference for other researchers to contribute to science.

2. For the author, hopefully after this research, the author can resume the study of linguistics so that it can be a useful knowledge.

3. For further researchers, who want to conduct studies in semiotics, especially semiotics related to culture, it was hoped that they will master linguistics and culture more so that they can find new discoveries. In addition, you can choose other semiotic studies focus such as semiotic analysis on films, advertisements, posters, and all things that have signs and meanings, to become new discoveries and contributions in the scientific world.

4. Readers are advised to increase their interest in reading. Reading increases knowledge. In this case the reader not only knows about semiotics in general, but can also know the meaning and value of everything, object, or ritual tradition so that they can take the value of goodness contained in it and appreciate the nation's cultural traditions.

\section{REFERENCES}

Chaer, A. (1994). Linguistik Umum. Jakarta: Rineka Cipta.

Barthes, R. (1967). Elements of Semiology. London: Jonthan Cape Ltd.

Danesi, M., \& Admiranto, A. (2010). Pengantar Memahami Semiotika Media. Yogyakarta: Jalasutra.

Koentjaraningrat. (1992). Kebudayaan, Mentalitas, dan Pembangunan. Jakarta: Gramedia Pustaka Umum.

Klan - Wikipedia bahasa Indonesia, ensiklopedia bebas. (2014). Id.wikipedia.org. Available: https://id.wikipedia.org/wiki/Klan [Accessed on April 04, 2021].

Linton, R. (1945). The Cultural Background of Personality. New York: Appleton. 
Miles, M., \& Huberman, M. (2014). Qualitative data analysis. London: SAGE. Moleong, Lexy J, 1991, Metodologi Penelitian Kualitatif, Bandung : PT. Remaja Rosdakarya

Moleong, L. (2017). Metodologi penelitian kualitatif. Bandung: PT Remaja Rosdakarya.

Newman, W. L. (1997). Social Research Methods Qualitative and Quantitative Approache. Boston: Allyn \& Bacon

Pateda, M. (2001). Semantik Leksikal. Jakarta: Rineka Cipta.

Pernikahan adat Karo - Wikipedia bahasa Indonesia, ensiklopedia bebas. (n.d.). Id.wikipedia.org. Available: https://id.wikipedia.org/wiki/Pernikahan_adat_Karo. [Accessed on April 04, 2021].

Piliang, Y. (1999). Hiper-Realitas Kebudayaan. Yogyakarta: Lembaga Kajian Islam dan Sosial.

Saussure, F. (1996). Pengantar Linguistik Umum. Yogyakarta, Indonesia: Gadjah Mada University Press.

Sebeok, T. (2001). Signs (2nd ed.). Toronto, Ont.: University of Toronto Press.

Sembiring, M. (2018). The Role of Rakut Si Telu in Karonese Society. Komunitas: International Journal of Indonesian Society and Culture, 78-85. Available : https://journal.unnes.ac.id/nju/index.php/komunitas/article/view/12054 [Accessed on August 29,2021]

Septyani Emilta Sitepu, A. (2019). Informasi Budaya Suku Karo Sumatera Utara. Jurnal Ilmu Informasi Perpustakaan dan Kearsipan, 413-420. Available : http://ejournal.unp.ac.id/index.php/iipk/article/view/107314/102767 [Accessed on August 28,2021]

Setiawan, E. (2012). Arti kata semiotika - Kamus Besar Bahasa Indonesia (KBBI) Online. Kbbi.web.id. Available: https://kbbi.web.id/semiotika [Accessed on April 05, 2021].

Singarimbun, M. (1975). Kindship, Descent and Alliance among Karo Batak. Berkeley: University of California Press.

Sobur, A. (2001). Analisis Teks Media: Suatu Pengantar Untuk Analisis Semiotik dan Analisis Farming. Bandung: Remaja Rosda Karya.

Sobur, A. (2006). Semiotika Komunikasi. Bandung: Remaja Rosdakarya.

Sui Yan, F. M. (2015). Reinterpreting some key concepts in Barthes's theory. Journal of Media and Communication 59 59-66. Available:https://academicjournals.org/journal/JMCS/article-full-textpdf/ABC767050719.[Accessed on April 04, 2021]. https://youtu.be/CGgOryfWe2c 